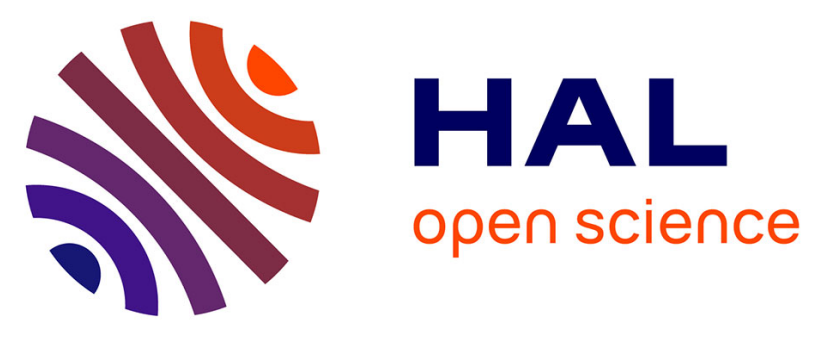

\title{
Can buy me love. Mate attraction goals lead to perceptual readiness for status products
}

Kim Janssens, Mario Pandelaere, Bram Van den Bergh, Kobe Millet, Inge Lensa, Keith Roe

\section{- To cite this version:}

Kim Janssens, Mario Pandelaere, Bram Van den Bergh, Kobe Millet, Inge Lensa, et al.. Can buy me love. Mate attraction goals lead to perceptual readiness for status products. Journal of Experimental Social Psychology, 2010, 47 (1), pp.254. 10.1016/j.jesp.2010.08.009 . hal-00918801

\section{HAL Id: hal-00918801 https://hal.science/hal-00918801}

Submitted on 15 Dec 2013

HAL is a multi-disciplinary open access archive for the deposit and dissemination of scientific research documents, whether they are published or not. The documents may come from teaching and research institutions in France or abroad, or from public or private research centers.
L'archive ouverte pluridisciplinaire HAL, est destinée au dépôt et à la diffusion de documents scientifiques de niveau recherche, publiés ou non, émanant des établissements d'enseignement et de recherche français ou étrangers, des laboratoires publics ou privés. 


\section{Accepted Manuscript}

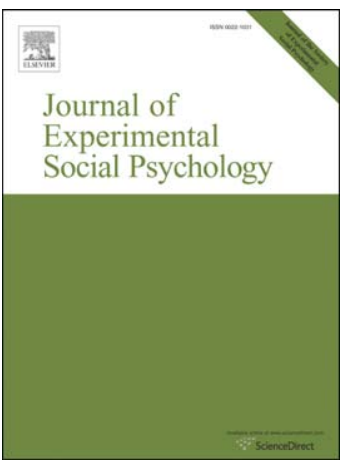

Can buy me love. Mate attraction goals lead to perceptual readiness for status products

Kim Janssens, Mario Pandelaere, Bram Van den Bergh, Kobe Millet, Inge Lensa, Keith Roe

PII:

S0022-1031(10)00181-2

DOI:

doi: 10.1016/j.jesp.2010.08.009

Reference:

YJESP 2522

To appear in: Journal of Experimental Social Psychology

Received date: 1 July 2010

Revised date: $\quad 10$ August 2010

Please cite this article as: Janssens, K., Pandelaere, M., den Bergh, B.V., Millet, K., Lensa, I. \& Roe, K., Can buy me love. Mate attraction goals lead to perceptual readiness for status products, Journal of Experimental Social Psychology (2010), doi: 10.1016/j.jesp.2010.08.009

This is a PDF file of an unedited manuscript that has been accepted for publication. As a service to our customers we are providing this early version of the manuscript. The manuscript will undergo copyediting, typesetting, and review of the resulting proof before it is published in its final form. Please note that during the production process errors may be discovered which could affect the content, and all legal disclaimers that apply to the journal pertain. 
Running head: PERCEPTUAL READINESS FOR STATUS PRODUCTS

Can buy me love. Mate attraction goals lead to perceptual readiness for status products.

Kim Janssens

KU Leuven

Mario Pandelaere

UGent

Bram Van den Bergh

Rotterdam School of Management, Erasmus University

Kobe Millet

KU Leuven

VU University, Amsterdam

Inge Lens

KU Leuven

Keith Roe

KU Leuven

VU University, Amsterdam 


\begin{abstract}
Exposure to mating cues activates the goal to signal one's mate value to members of the opposite sex. This mate attraction goal may render men perceptually ready for products that signal their mate value to women. As men's mate value is partly determined by their financial prospects, men may be more likely to notice products that would signal their financial resources to women. The current study demonstrates that exposure to a sexily dressed woman increases single men's likelihood of noticing status products in a visual display. Not only do these findings further support the link between conspicuous consumption and male mating strategies, they are the first to demonstrate perceptual readiness for indirect (i.e., products) rather than direct (i.e., opposite sex individuals) means for reproduction.
\end{abstract}

KEYWORDS: perceptual readiness; mate attraction; visual attention; conspicuous consumption; status products 
Can buy me love. Mate attraction goals lead to perceptual readiness for status products.

Exposure to sexy women or images thereof increases men's temporal impatience for money (Van den Bergh, Dewitte, \& Warlop, 2008; Wilson \& Daly, 2004), heightens their selfreported financial aspirations and ambition (Roney, 2003), and even interferes with their cognitive functioning (Karremans, Verwijmeren, Pronk, \& Reitsma, 2009). Presumably, exposure to mating cues-like (images of) sexy women-triggers a mating goal in men (Maner, Gailliot, \& DeWall, 2007a), which, in turn, raises men's interest in means that would help to reach this goal. The current report shows that exposure to mating cues increases single men's perceptual readiness for status goods, testifying to a spontaneous activation of financial concern following the activation of a mating goal.

\section{THEORETICAL BACKGROUND}

Over the course of our evolutionary past sex differences in minimum parental investment have given rise to sex differences in mate preferences (Bjorklund \& Shackelford, 1999; Trivers, 1972). Men have an evolved preference for mates who are physically attractive (Buss \& Barnes, 1986; Feingold, 1992). In particular, men favor potential mates who exude youth and health (Buss \& Schmitt, 1993) as these qualities signal female fertility (Buss \& Barnes, 1986). In contrast, women have developed a preference for men who are willing and able to invest maximally in their partner and offspring (Geary, 2000). Adequate economical resources serve as a potent investment cue (Hill \& Buss, 2008). Therefore, women tend to prefer men with great ambition and diligence, traits related to high social status and financial prosperity (Li, Bailey, Kenrick, \& Linsenmeier, 2002). 
For both men and women, reproduction involves two subgoals. The mate selection goal involves screening opposite sex individuals. This allows men and women to eliminate non-suitable mates from consideration and to focus on suitable prospects. At the same time, men and women not only want to detect a suitable partner but also want to demonstrate their own mating value to the potential partners they are interested in. The latter goal is the mate attraction goal. Mate attraction involves signaling that one possesses the traits that the opposite sex values. The current paper focuses on the male mate attraction goal.

Goals lead the cognitive system in pursuit of a desired end state. Goal activation leads to a more positive evaluation of objects that serve to attain the activated goal (i.e., evaluative readiness, Ferguson, 2008) which makes the object more likely to be approached (Ferguson $\&$ Bargh, 2004). For instance, sandwiches become more attractive when people are hungry (Goukens, Dewitte, Pandelaere, \& Warlop, 2007). At the same time, an activated goal may render people more likely to notice objects in their environment that serve to attain it (i.e., perceptual readiness, Bruner, 1957). For example, thirsty people are more apt to notice or identify words associated with means that directly serve to reduce one's thirst, like water, soda, juice, cup, glass, bottle, and to notice a bottle of water in their environment (Aarts, Dijksterhuis, \& De Vries, 2001).

The activation of a mate selection goal leads to perceptual readiness to notice attractive opposite sex members in one's environment (e.g., Maner and colleagues, 2003, 2007a, 2007b). Also, around ovulation, women display perceptual readiness for attractive men (Anderson et al., in press). In turn, the activation of a mate attraction goal leads to evaluative readiness, or an increased intention to signal one's own mating value (Griskevicius et al., 2007). For men, this entails signaling their (potential) access to financial resources. Hence, after exposure to mating cues, men report more ambition and report attaching more importance to wealth (Roney, 2003). Because consumption of status products signals that the 
owner has the ability to acquire a high social status and corresponding resources (Colarelli \& Dettmann, 2003; Wegener, 1992), it signals men's mate quality (Saad, 2007); this idea is supported by the link between public status consumption and testosterone levels in men (Saad \& Vongas, 2009). Accordingly, after inducing romantic desires, men express a higher intent to purchase luxury products or expensive brands and a lower intent to spend on functional products (Griskevicius et al., 2007).

\section{PRESENT RESEARCH}

While several studies indicate that mating cues lead to an evaluative readiness in men for status consumption (e.g., Griskevicius et al., 2007; Sundie et al., in press), we show that mating cues also lead to perceptual readiness for status products. This extends prior research as it shows that mating cues not only trigger concern about financial resources through the process of deliberate, strategic thinking-as is potentially the case in studies on evaluative readiness-but also more spontaneously. In this regard, it is also important that, in contrast to many previous studies that demonstrate a link between conspicuous consumption and mating, the mating goal was activated implicitly, and outside any experimental task, through the presence of a sexily dressed female experimenter. Further, extant research on the effects of mating cues on men's interest in conspicuous consumption has ignored relationship status. We show that the impact of mating cues is not equally effective for single men and men in a committed relationship.

Finally, from a more general point of view, existing demonstrations of goal-directed perceptual readiness typically focus on means that are directly relevant to attain the activated goal (e.g., drinks for thirsty people). Our demonstration of perceptual readiness for status products following the activation of a mating goal suggests that goal activation may lead to 
perceptual readiness for means that strategically rather than directly serve the attainment of an activated goal.

\section{Method}

One hundred and thirty-three male students participated, varying in age from 17 to 32 years $(M=20, S D=1.79)$. They received a participation fee of $€ 6$. We manipulated the presence or absence of a mating cue through the clothing and appearance of the female experimenter. Two conditions were created, to which participants were randomly assigned: The experimenter was either plainly (control condition, see photo 1 in Appendix A) or sexily dressed (mating cue condition, see photo 2 in Appendix A). Participants entered the lab individually and interacted briefly with the female experimenter, who was blind to the experimental hypotheses. Afterwards, participants engaged in the status display task and subsequently indicated their relationship status.

Status display task. Participants engaged in a computerized visual display task (cf. Roskos-Ewoldsen \& Fazio, 1992). They were exposed to ten different displays, each consisting of six different product pictures (see Appendix B). Each display remained on screen for one second and contained one picture of a status product (Breitling watch, Porsche, Aston Martin, laser keyboard, exclusive mansion, I-mate, I-pod, Maserati, Mont Blanc pen, and home cinema system) and five pictures of functional products (e.g., stapler, towel, mug, umbrella), randomly arranged in a circle. After exposure to each display, participants had 25 seconds to write down as much products as possible after which they were exposed to the subsequent display. The recall task was unaided and participants were not asked for specific brand names, but for general product categories. 
In a pretest, the 60 pictures were rated on conspicuousness ("to what extent may this product be used to show off"?) and on expensiveness ("how expensive do you think this product is"?), with scales anchored on 1 (not at all) and 7 (very much). The ten selected status products scored higher on conspicuousness $\left(M_{\text {status }}=6.04, S D=0.82\right.$ vs $M_{\text {functional }}=2.52, S D=$ $1.20, t(58)=-8.85, p<.001)$ as well as on expensiveness $\left(M_{\text {status }}=6.23, S D=0.63\right.$ vs. $M$ functional $=2.96, S D=1.20, t(24.52)=-12.52, p<.001)$ than the functional products.

Relationship status. To check to what extent participants were involved in a (serious) relationship, they indicated their relationship status on a seven-point Likert scale ranging from 1 (I am single) to 7 (I am married). Participants $(n=5)$ who indicated 'I have a relationship since a couple of days/weeks' (score 3) were excluded as they neither were single nor yet seriously involved in a relationship. Each participant received a dichotomous relationship status score: single $(n=72)$ (responses $<3)$ or in a committed relationship $(n=61)$ (responses $>3$ ). Results are similar, however, if relationship status is treated as an interval-level variable.

\section{Results}

Across the ten displays, we calculated the proportion of products recalled for status products and for functional products separately. A three-way ANOVA with Mating cue (sexy vs. plain) and Relationship status (single vs. committed) as between-subjects factors and Product type (status product vs. functional product) as within-subjects factor was conducted on the proportion of products recalled. Most relevant for our hypotheses, a three-way interaction between Mating cue, Relationship status, and Product type was obtained, $F(1,129)=4.42, p$ $=.04$ (see Figure 1). While participants in committed relationships recalled the same proportion of status products in both experimenter conditions $\left(M_{\mathrm{sexy}}=.33, S D=.13\right.$ vs. $M_{\text {plain }}=$ $.35, S D=.17), t(129)=.43, p=.67$, single men recalled a significantly higher proportion of 
status products after exposure to the sexily dressed experimenter $(M=.43, S D=.17)$ than after exposure to the plainly dressed experimenter $(M=.33, S D=.15), t(129)=-2.80, p<$. 01.

Probably due to a trade-off in attention (increased attention to one product necessarily decreases attention to other products, particularly in the limited time span of one second), single men recalled less functional products after exposure to the sexily dressed experimenter $(M=.31, S D=.06)$ than after exposure to the plainly dressed experimenter $(M=.34, S D=$. 06), $t(129)=1.92, p=.057$.

Insert Figure 1 about here

In addition to the three-way interaction, a significant two-way interaction between Product type and Mating cue, $F(1,129)=4.53, p=.03$, indicated that recall of status products was higher after exposure to the sexily dressed experimenter $(M=.38, S D=.15)$ than after exposure to the plainly dressed experimenter $(M=.34, S D=.16), t(129)=-1.60, p$ $=.11$ but recall of functional products was lower in the former condition $(M=.31, S D=.06)$ than in the latter one $(M=.33, S D=.05), t(129)=2.34, p=.02$. As the three-way interaction indicates, this two-way interaction was entirely driven by the results for single men. Finally, a significant main effect of Product type, $F(1,129)=6.91, p=.01$, indicated that, overall, a higher proportion of the status products $(M=.36, S D=.16)$ was recalled than of the functional products $(M=.32, S D=.05)$.

\section{DISCUSSION}

Our study shows that exposure to a sexily dressed female experimenter increases single men's attention to status products. This extends previous research on the effect of mating cues in 
several ways. Previous studies have shown that exposure to mating cues increases men's selfreported intention to engage in conspicuous consumption (Griskevicius et al., 2007; Sundie et al., in press) and self-reported importance they attach to financial resources (Roney, 2003).

However, self-report measures may invite participants to reflect on the activated mating goal. A self-reported interest in status products may therefore be due to deliberate, strategic thinking. Our study demonstrates that mating cues spontaneously activate interest in status products in men. This interpretation is strengthened by the implicit activation of the mating goal, through the appearance of the female experimenter, and the short exposure to each visual display.

Men in a committed relationship exhibit a diminished attention to attractive alternative mates (Maner, Gailliot, \& Miller, 2009). Our research indicates that men in a committed relationship also show less attention to the means to attract mates. In addition, so far, studies on the link between mating motives and conspicuous consumption have ignored relationship status, although Sundie et al. (in press) show a moderation of the effect of mating cues on self-reported interest in conspicuous consumption by sociosexuality. As relationship status and sociosexuality are not identical concepts, future research may benefit from examining the empirical relation between them.

Finally, our study also extends extant demonstrations of goal-directed perceptual readiness more generally. To the best of our knowledge, perceptual readiness following goal activation always deals with means that are directly related to the activated goal. For example, Aarts et al. (2001) show that thirsty people display perceptual readiness for objects that may mitigate their thirst. Also, Maner and colleagues (2003, 2007a, 2007b) show that the activation of a mating goal leads to an increased readiness to perceive attractive opposite sex members to have sex with. Our paper contributes to the literature by showing that goal activation leads to perceptual readiness even for means which do not obviously serve to attain 
a goal but extends to "strategic means". This suggests that perceptual readiness may be more ubiquitous than currently surmised.

Our study also raises several issues to be addressed in future research. First, future research may investigate why mating cues exert less influence on men in a committed relationship than on single men. Possibly, a mating cue does not activate a mating goal in them as their mating goal is already met. Alternatively, exposure to mating cues may be threatening for men in a committed relationship. Due to this threat, the perception of mating cues may trigger inhibitory processes that deactivate any mate attraction goal for men in committed relationships. If so, these inhibitory processes may more likely be triggered in the presence of a real threat (i.e., a real sexy woman) than in the presence of a fictional threat (i.e., a picture of a sexy woman; for a comparison of tangible and non-tangible temptations, see Geyskens, Dewitte, Pandelaere, \& Warlop, 2008).

Second, while our study suggests that single men in a mating mindset show an increased attention for status products, our procedure does not allow disentangling visual attention processes from memory processes. To corroborate our interpretation of our findings, subsequent research may use eye-tracking methodology to better capture the pure visual attention processes. Third, while the current study focuses on men future research might also examine the effect of mating cues on women. Given that men prefer mates who exude beauty and youth, women might attempt to increase their mate value by enhancing their attractiveness. Activating a mate attraction goal might lead to an increased evaluative and perceptual readiness for beauty-enhancing consumer products.

To conclude, our study is the first, to our knowledge, that shows that mating cues may not only trigger single men's interest in status products but also directs their attention towards them. This difference is not only important from a theoretical point of view as it testifies to a spontaneously triggered association between mating goal activation and concern with 
conspicuous consumption, but also from a practical one. For instance, in a sales context, visual attention may increase the likelihood of a purchase. Hence, the mere presence of a sexy woman in a sales context may suffice to increase sales of high-ticket items, particularly for single men. 
Author Note

Kim Janssens, School for Mass Communication Research, KU Leuven, Belgium; Mario Pandelaere, Department of Marketing, UGent, Belgium; Bram Van den Bergh, Rotterdam School of Management, Erasmus University, The Netherlands; Kobe Millet, Research group Marketing, KU Leuven, Belgium and Faculty of Economics and Business Administration, VU Amsterdam, The Netherlands; Inge Lens, Research group Marketing, KU Leuven, Belgium; Keith Roe, School for Mass Communication Research, KU Leuven, Belgium, and Department of Communication, VU Amsterdam, The Netherlands.

Financial support to the second author from the Research Foundation - Flanders (FWO) and to the second and fifth author from the K.U Leuven is gratefully acknowledged.

Correspondence concerning this article can be addressed to Mario Pandelaere, Department of Marketing, Ghent University, Tweekerkenstraat 2, 9000 Gent, Belgium, telephone number: $+32(0) 9.264 .35 .20$, fax number: +32(0)9.264.42.79. E-mail: Mario.Pandelaere@ugent.be 


\section{References}

Aarts, H., Dijksterhuis, A, \& De Vries, P. (2001). On the psychology of drinking: Being thirsty and perceptually ready. British Journal of Psychology, 92, 613-642.

Anderson, U. S., Perea, E. F. P., Becker, D. V., Ackerman, J. M., Shapiro, J. R., Neuberg, S. L., \& Kenrick, D. T. (in press). I only have eyes for you: Ovulation redirects attention (but not memory) to attractive men. Journal of Experimental Social Psychology.

Bjorklund, D. F., \& Shackelford, T. K. (1999). Differences in parental investment contribute to important differences between men and women. Current directions in Psychological Science, 8, 86-89.

Bruner, J. S. (1957). On perceptual readiness. Psychological Review, 64 (2), 123-152.

Buss, D. M., \& Barnes, M. (1986). Preferences in human mate selection. Journal of Personality and Social Psychology, 50 (3), 559-570.

Buss, D. M., \& Schmitt, D. P. (1993). Sexual strategies theory: An evolutionary perspective on human mating. Psychological Review, 100 (2), 204-232.

Colarelli, S. M., \& Dettmann, J. R. (2003). Intuitive evolutionary perspectives in marketing practices. Psychology and Marketing, 20, 837-865.

Feingold, A. (1992). Gender differences in mate selection preferences: A test of the parental investment model. Psychological Bulletin, 112 (1), 125-139.

Ferguson, M. J. (2008). On becoming ready to pursue a goal you don't know you have:

Effects of nonconscious goals on evaluative readiness. Journal of Personality and Social Psychology, 95 (6), 1268-1294.

Ferguson, M. J., \& Bargh, J. A. (2004). Liking is for doing: The effects of goal pursuit on automatic evaluation. Journal of Personality and Social Psychology, 87 (5), 557-572. 
Geary, D. C. (2000). Evolution and proximate expression of human paternal investment. Psychological Bulletin, 126 (1), 55-77.

Geyskens, K., Dewitte, S., Pandelaere, M., \& Warlop, L. (2008). Tempt me just a little bit more: The effect of prior food temptation actionability on goal activation and consumption. Journal of Consumer Research, 35, 600-610.

Goukens, C., Dewitte, S., Pandelaere, M., \& Warlop, L. (2007). Wanting a bit(e) of everything. Extending the valuation effect to variety seeking. Journal of Consumer Research, 34, 386-394.

Griskevicius, V., Tybur, J. M., Sundie, J. M., Cialdini, R. B., Miller, G. F., \& Kenrick, D. T. (2007). Blatant benevolence and conspicuous consumption: When romantic motives elicit strategic costly signals. Journal of Personality and Social Psychology, 93 (1), $85-102$.

Hill, S. E., \& Buss, D. M. (2008). The mere presence of opposite-sex others on judgments of sexual and romantic desirability: Opposite effects for men and women. Personality and Social Psychology Bulletin, 34, 635-647.

Karremans, J. C., Verwijmeren, T., Pronk, T. M., \& Reitsma, M. (2009). Interacting with women can impair men's cognitive functioning. Journal of Experimental Social Psychology, 45, 1041-1044.

Li, N. P., Bailey, J. M., Kenrick, D. T., \& Linsenmeier, J. A. W. (2002). The necessities and luxuries of mate preferences: Testing the tradeoffs. Journal of Personality and Social Psychology, 82 (6), 947-955.

Maner, J. K., Gailliot, M. T., \& DeWall, C. N. (2007a). Adaptive attentional attunement: Evidence for mating-related perceptual bias. Evolution and Human Behavior, 28, 28-36. 
Maner, J. K., Gailliot, M. T., \& Miller, S. L. (2009). The implicit cognition of relationship maintenance: Inattention to attractive alternatives. Journal of Experimental Social Psychology, 45, 174-179.

Maner, J. K., Gailliot, M. T., Rouby, D. A., \& Miller, S. L. (2007b). Can’t take my eyes off you: Attentional adhesion to mates and rivals. Journal of Personality and Social Psychology, 93 (3), 389-401.

Maner, J. K, Kenrick, D. T., Becker, D. V., Delton, A. W., Hofer, B., Wilbur, C. J., \& Neuberg, S. L. (2003). Sexually selective cognition: Beauty captures the mind of the beholder. Journal of Personality and Social Psychology, 85 (6), 1107-1120.

Roney, J. R. (2003). Effects of visual exposure to the opposite sex: Cognitive aspects of mate attraction in human males. Personality and Social Psychology Bulletin, 29 (3), 393-404.

Roskos-Ewoldsen, D. R., \& Fazio, R. H. (1992). On the orienting value of attitudes: Attitude accessibility of an object's attraction of visual attention. Journal of Personality and Social Psychology, 63 (2), 198-211.

Saad, G. (2007). The Evolutionary Bases of Consumption. Mahwah, NJ: Lawrence Erlbaum.

Saad, G., \& Vongas, J. G. (2009). The effect of conspicuous consumption on men's testosterone levels. Organizational Behavior and Human Decision Processes, 110, $80-92$.

Sundie, J. M., Kenrick, D. T., Griskevicius, V., Tybur, J. M., Vohs, K. D., \& Beal, D. J. (in press). Peacocks, Porsches, and Thorsten Veblen: Conspicuous consumption as a sexual signaling system. Journal of Personality and Social Psychology.

Trivers, R. L. (1972). Parental investment and sexual selection. In B. G. Campbell (Ed.), Sexual selection and the descent of man (pp. 136-179). Chicago: Aldine. 
Van den Bergh, B., Dewitte, S., \& Warlop, L. (2008). Bikinis instigate generalized impatience in intertemporal choice. Journal of Consumer Research, 35, 85-97.

Wegener, B. (1992). Concepts and measurement of prestige. Annual review of Sociology, 18, 253-280.

Wilson, M., \& Daly, M. (2004). Do pretty women inspire men to discount the future? Proceedings of the Royal Society B, 271, 177-179. 
Appendix A: Experimental Manipulation

Photo 1: plainly dressed experimenter

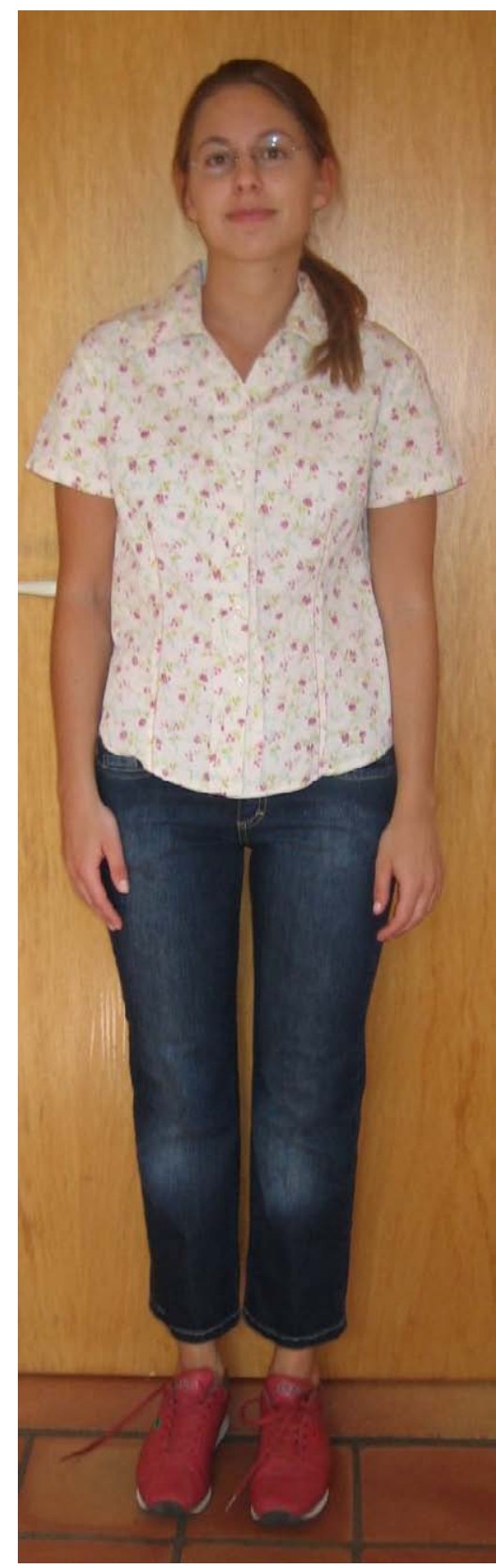

Photo 2: sexily dressed experimenter

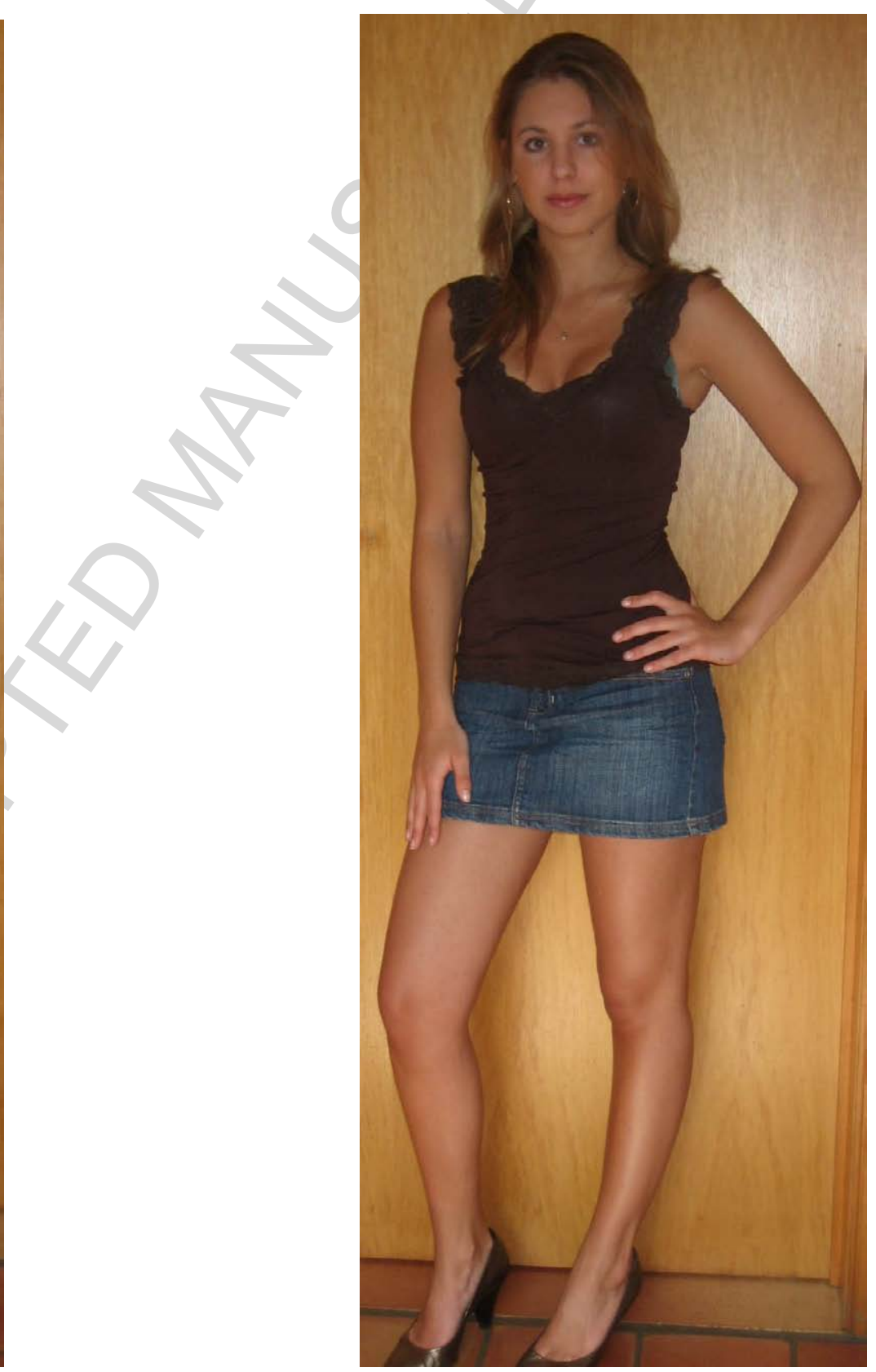


Appendix B: Example of a Visual Display
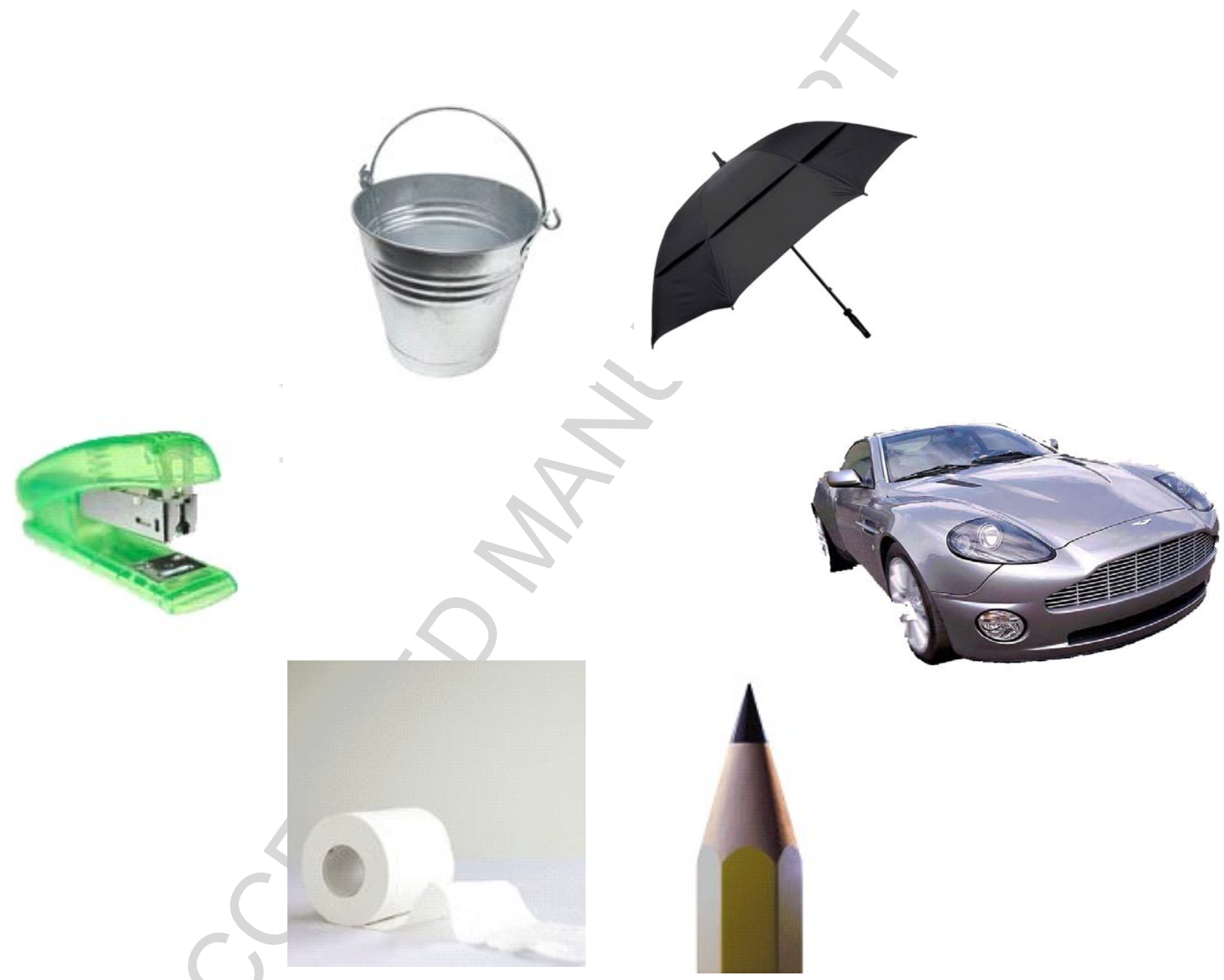
Figure 1. Proportion of products recalled

status products recalled

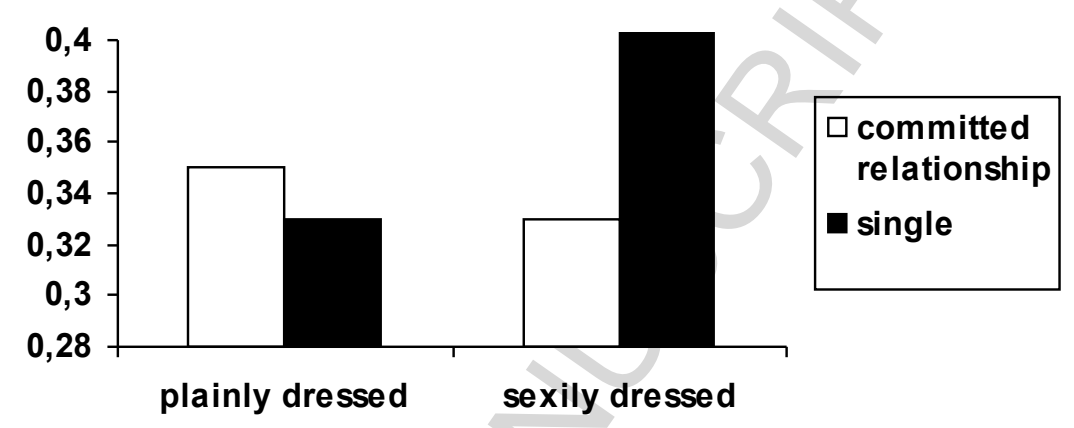

functional products recalled

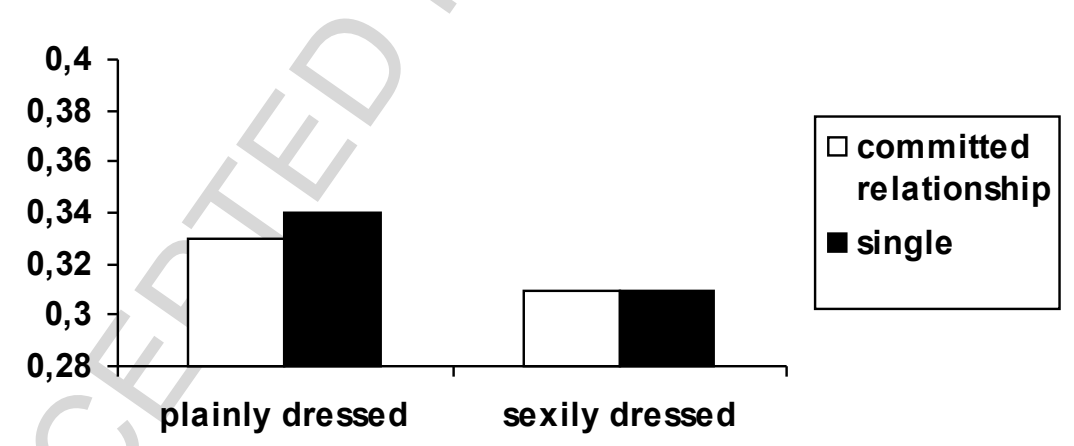

